\title{
SILVO TORKAR
}

\section{SEDEMNAJSTA MEDNARODNA KONFERENCA ONOMASTIKA POVOLŽJA (2019)} 2019

Veliki Novgorod (prilastek Veliki je uradno prejel šele leta 1999) je rojstni kraj ruske državnosti s konca 9. stoletja in središče znamenite srednjeveške Novgorodske republike. Znan je tudi kot nahajališče nad tisoč »listin« na brezovem lubju (berestjanýh grámot) iz 11.-15. stoletja, napisanih v staronovgorodskem narečju. V tem mestu je od 18. do 20. septembra 2019 potekala 17. mednarodna znanstvena konferenca Onomastika Povolžja, čeprav skozi mesto sicer teče reka Volhov, do izvira Volge pa je približno tri ure vožnje. Konferenco je organizirala Novgorodska državna univerza Jaroslava Modrega oziroma njena Humanistična fakulteta (univerza je bila ustanovljena leta 1993 iz dveh dotedanjih fakultet, Pedagoške in Politehniške). Od 112 referatov, že objavljenih v zborniku konference, jih je bilo na konferenci predstavljenih 70. Zastopani so bili tako veliki univerzitetni centri Rusije (Moskva, Sankt Peterburg, Jekaterinburg, Perm, Voronež, Kazan, Ufa, Samara, Novosibirsk, Irkutsk, Tjumen) kot tudi srednje velika in manjša središča (Petrozavodsk, Pskov, Smolensk, Tver, Kostroma, Jaroslavelj, Vologda, Iževsk, Čeboksari, Kemerovo, Ulan-Ude, Jakutsk, Orenburg, Mahačkala idr.), obenem pa tudi nekaj centrov iz drugih držav (Belorusije, Poljske, Slovenije, Srbije, Kazahstana in Turčije, medtem ko so Ukrajinci sodelovali le z objavami).

Prvo konferenco pod naslovom Onomastika Povolžja je organiziral leta 1967 v Uljanovsku (nekdanjem Simbirsku) eden od utemeljiteljev sovjetske onomastike, Vladimir Andrejevič Nikonov (1904-1988). Pozneje so konference pod istim naslovom potekale v Nižnem Novgorodu (1969, od 1932 do 1990 se je imenoval Gorki), baškirski prestolnici Ufi (1971), Penzi (1973), mordovski prestolnici Saransku (1974), Volgogradu (1989, 1995, 1998, 2002), ponovno v Ufi (2006), marijski prestolnici Joškar-Oli (2008), tatarski prestolnici Kazanu (2010), Jaroslavlju (2012), Tveru (2014), Arzamasu (2016) in ob 50-letnici ponovno v Uljanovsku (2017).

Tokratno konferenco je pripravil odbor na čelu s predsednikom Valerijem Leonidovičem Vasiljevom, profesorjem na katedri za filologijo Humanistične 
fakultete in sopredsedujočim Vasilijem Ivanovičem Suprunom, profesorjem Volgograjske državne socialno-pedagoške univerze, sicer predsednikom stalnega organizacijskega odbora konferenc Onomastika Povolžja.

$\mathrm{Na}$ konferenci je bila obravnavana zelo raznovrstna onomastična problematika. Prvi dan so potekala plenarna predavanja, drugega dne pa je delo potekalo v sedmih sekcijah: Zgodovinsko-etimološki vidiki regionalne toponimije, Viri in metode proučevanja toponimije in mikrotoponimije, Mestno onomastično okolje, Vprašanja antroponimije, Teorija in metode onomastičnih raziskav, Vidiki onomastične periferije ter Literarna in folklorna onomastika. Večina referatov je obravnavala različne imenske kategorije v ruskem jezikovnem okolju, nekateri avtorji (vštevši tiste, ki so prispevali samo pisno objavo) pa so se ukvarjali z onomastično problematiko različnih neslovanskih jezikov severne Rusije, Povolžja, Urala, Sibirije in Japonske, npr. karelščine, ugrofinskega substrata, laponščine, mordvinščine, čuvaščine, tatarščine, baškirščine, burjatščine in jakutščine. Posamezni referati so bili posvečeni vprašanjem jezikovnih stikov in medjezikovnih vzporednic ruščine in različnih neruskih jezikov Rusije, a tudi kitajščine.

Tretji dan je bil posvečen poročilom o delu posameznih sekcij in ekskurziji v Ilmensko Pojezerje in Jurjev samostan (iz leta 1119). Tudi drugega dne konference je bilo pozno popoldne namenjeno ekskurziji na Rurikovo gradišče ilmenskih Slovenov (s konca 9. stoletja) in v Hutinski samostan (iz leta 1192).

Med vidnejšimi imeni nastopajočih velja omeniti Irmo Mullonen iz Karelije, Sergeja Gorjajeva in Ano Makarovo iz Jekaterinburga, Irino Ganžino iz Tvera, Alekseja Burykina iz Sankt Peterburga (ki se je proslavil z najnovejšo hipotezo o avtorstvu Pesnitve o Igorjevem pohodu), Ano Mezenko in Igorja Kopylova iz Belorusije, Genadija Kovaljova in Sergeja Popova (avtorja spletne strani Onomastika Rossii) iz Voroneža in Ljudmilo Klimkovo iz Arzamasa, med raziskovalci, ki niso utegnili dopotovati, pa naj omenim Sergeja Myznikova iz Sankt Peterburga, Aleksandra Šapošnikova iz Moskve in Viktorja Šulgača iz Kijeva. Podpisani sem predstavil referat o etimologiji zemljepisnih imen Kolezija in Rezija.

Naslednja konferenca iz cikla Onomastika Povolžja bo potekala septembra 2020 v Kostromi. 